\title{
Evaluation of the sensitivity and specificity of criteria for isolation of patients admitted to a specialized cancer hospital
}

\author{
Caroline Cataneo ${ }^{1}$ \\ Silvia Rita Marin da Silva Canini \\ Paulo de Tarso Oliveira e Castro ${ }^{3}$ \\ Miyeko Hayashida ${ }^{4}$ \\ Elucir $\mathrm{Gir}^{5}$
}

Early isolation of patients possibly colonized by multi-resistant microorganisms can minimize their spread, reducing cases of hospital infection and the related costs. This study aimed to identify the sensitivity and specificity of the criteria for isolation of patients admitted to a specialized cancer hospital. Cross-sectional study with a population of 61 patients coming from other hospitals who were admitted to the hospital between March $1^{\text {st }}$ and August $31^{\text {th }}, 2009$. At the moment of admission, a data collection instrument was filled out and nasal and anal swabs were collected for microbiological culture. Of the 56 patients who met the isolation criteria, 30 (49.2\%) presented positive cultures for multi-resistant microorganisms and methicillin-resistant Staphylococcus aureus was the most frequently identified microorganism. Most patients colonized by multi-resistant microorganisms were isolated at the moment of admission. The sensitivity of the isolation criteria was $90 \%$ and the specificity was $6.5 \%$.

Descriptors: Hospital Infection; Drug Resistance, Microbial; Patient Isolation; Nursing.

\footnotetext{
${ }^{1}$ RN, Hospital de Câncer de Barretos, SP, Brazil. Master's Student, Escola de Enfermagem de Ribeirão Preto, Universidade de São Paulo, WHO Collaborating Centre for Nursing Research Development, SP, Brazil. E-mail: carocataneo@ig.com.br.

${ }^{2}$ RN, Ph.D. in Nursing, Professor, Escola de Enfermagem de Ribeirão Preto, Universidade de São Paulo, WHO Collaborating Centre for Nursing Research Development, SP, Brazil. E-mail: canini@eerp.usp.br.

${ }^{3}$ Infectious Disease Physician, Hospital de Câncer de Barretos, Brazil. E-mail: ccih@hcancerbarretos.com.br.

${ }^{4}$ RN, Ph.D. in Nursing, Escola de Enfermagem de Ribeirão Preto, Universidade de São Paulo, WHO Collaborating Centre for Nursing Research Development, SP, Brazil. E-mail: miyeko@eerp.usp.br.

${ }^{5}$ RN, Ph.D. in Nursing, Full Professor, Escola de Enfermagem de Ribeirão Preto, Universidade de São Paulo, WHO Collaborating Centre for Nursing Research Development, SP, Brazil. E-mail: egir@eerp.usp.br.
}

Corresponding Author:

Silvia Rita Marin da Silva Canini

Universidade de São Paulo. Escola de Enfermagem de Ribeirão Preto

Departamento de Enfermagem Geral e Especializada

Av. dos Bandeirantes, 3900

Bairro: Monte Alegre

CEP: 14040-902, Ribeirão Preto, SP, Brasil

E-mail: canini@eerp.usp.br 


\title{
Avaliação da sensibilidade e da especificidade dos critérios para isolamento de pacientes admitidos em um hospital especializado em oncologia
}

$\mathrm{O}$ isolamento precoce de pacientes, possivelmente colonizados por microrganismos multirresistentes, pode minimizar sua disseminação, reduzindo os casos de infecção hospitalar e os custos associados. O objetivo deste estudo foi identificar a sensibilidade e especificidade dos critérios para isolamento de pacientes admitidos num hospital especializado em oncologia. Como método, usou-se o estudo transversal. A população foi composta por 61 pacientes, admitidos no período de 10 março a 31 de agosto de 2009, e procedentes de outros hospitais. Foi preenchido instrumento de coleta de dados no momento da admissão e colhidas amostras da região nasal e anal para cultura microbiológica. Os resultados mostraram que, dos 56 pacientes que preencheram os critérios de isolamento, $30(49,2 \%)$ tiveram culturas positivas para microrganismos multirresistentes e o Staphylococcus aureus resistente à oxacilina foi o mais frequentemente identificado. A maioria dos pacientes colonizados foi isolada no momento da admissão. Conclui-se que a sensibilidade dos critérios para isolamento foi de $90 \%$ e a especificidade de $6,5 \%$.

Descritores: Infecção Hospitalar; Resistência Microbiana a Medicamentos; Isolamento de Pacientes; Enfermagem.

\section{Evaluación de la sensibilidad y especificidad de los criterios para aislamiento de pacientes admitidos en un hospital especializado en oncología}

\begin{abstract}
El aislamiento precoz de pacientes posiblemente colonizados por microorganismos multirresistentes puede minimizar su diseminación, reduciendo los casos de infección hospitalaria y los costos asociados. El objetivo de este estudio fue identificar la sensibilidad y especificidad de los criterios para aislamiento de pacientes admitidos en un hospital especializado en oncología. Se trata de un estudio transversal cuya población fue compuesta por 61 pacientes admitidos en el período de 01 marzo a 31 de agosto de 2009 y procedentes de otros hospitales. Fue llenado un instrumento de recolección de datos en el momento de la admisión y recogidas muestras de la región nasal y anal para cultura microbiológica. De los 56 pacientes que llenaron los criterios de aislamiento, 30(49,2\%) tuvieron culturas positivas para microorganismos multirresistentes y el Staphylococcus aureus resistente a la oxacilina fue el más frecuentemente identificado. La mayoría de los pacientes colonizados fue aislada en el momento de la admisión. La sensibilidad de los criterios para aislamiento fue de $90 \%$ y la especificidad de $6,5 \%$.
\end{abstract}

Descriptores: Infección Hospitalaria; Farmacorresistencia Microbiana; Aislamiento de Pacientes; Enfermería.

\section{Introduction}

The gradual increase in microorganisms' resistance to antimicrobials used in clinical practice has effectively contributed for hospital infection to be considered a public health problem, not only in Brazil, but in most countries around the world(1).
Hospital infections are highly relevant in epidemiological terms, in the primary health care context as well as in hospital care, because they contribute to the rise in morbidity and mortality rates and the extension of patients' hospital stay, consequently increasing treatment $\operatorname{costs}^{(2)}$. 
Risk factors for catching hospital infections can be endogenous, such as age, use of immunosuppressors, antimicrobials and chemotherapy, nutritional status, presence of chronic illness, prolonged hospitalization, baseline disease, among others: or exogenous factors like cross-infection, invasive procedures, use of contaminated materials and equipment, low adherence to hand washing, inadequate environmental cleaning and disinfection, presence of vectors like insects and rodents ${ }^{(3)}$

In cancer patients, risk factors can overlap as, besides the immune suppression the disease itself causes, they are submitted to surgical treatment, chemotherapy and/or radiotherapy. Chemotherapyinduced neutropenia represents one of the main infection risks in this population(4).

According to the National Health Surveillance Agency (ANVISA), about $10 \%$ of hospitalized patients are infected due to invasive procedures and/or immune suppressing therapy. Patients with a positive culture for resistant microorganisms defined according to each hospital's criteria and who do not give signs of an infectious process are considered colonized by multiresistant microorganisms, while patients with a positive culture and infectious signs are considered infected ${ }^{(5)}$.

The bacteria that commonly cause illnesses in immune suppressed patients are the same that affect immune competent people. Gram-positive bacteria are responsible for 60 to $70 \%$ of infection episodes microbiologically documented in neutropenic patients and the most frequent microorganisms are coagulasenegative staphylococcus and vancomycin resistant enterococcus ${ }^{(6)}$.

Infectious complications in oncology patients tend to be severe and potentially fatal, which justifies prevention and control measures. According to the Guideline "Management of multidrug-resistant organisms in healthcare settings"(7), the interventions recommended for multi-resistant microorganism control in health services are grouped in seven categories, which are: administrative support, judicious use of antimicrobials, routine surveillance, use of standard and contact precautions, environmental measures and decolonization.

Active surveillance has been appointed as an important component of multi-resistant microorganism control programs, as it permits the early detection of emerging microorganisms, monitoring of epidemiological trends and verifying the efficacy of the adopted interventions. Various strategies have been used to detect asymptomatic colonization, including material collection for surveillance culture and, more recently, the use of predictors, aka clinical criteria, such as hospitalization time, use of antibiotics therapy and previous hospitalization at an intensive care unit(7-8).

Surveillance culture has been appointed as the most sensitive approach to identify colonized patients. Some studies recommend its accomplishment in all hospital-admitted patients, independently of risk criteria assessments $^{(9-10)}$. The time spent on microbiological tests and the high cost of this procedure, however, have hampered the practice of this routine at most hospitals. Therefore, the use of clinical criteria is a promising and less costly option in comparison with surveillance cultures $^{(8)}$.

In view of this panorama, the present study was accomplished to identify the sensitivity and specificity of isolation criteria for patients admitted to a specialized cancer hospital. The researchers hope this kind of studies can contribute to put in practice contact precautions during patient admission to health institutions.

\section{Material and Method}

A cross-sectional study was developed at Hospital de Câncer de Barretos -São Paulo, which is a specialized cancer hospital and considered a national referral institution for cancer treatment.

Approval for the research project was obtained from the hospital's Institutional Review Board (process No 180/2008). Subjects who agreed to participate signed the Informed Consent Term.

The study population comprised 61 patients aged 18 years or older, hospitalized between March $1^{\text {st }}$ and August $31^{\text {st }}$ 2009, who were previously hospitalized in other institutions.

Two instruments were elaborated for data collection, the first to collected demographic data (age and gender), clinical data like hospitalization type, baseline illnesses and presence of invasive procedures, besides the following clinical criteria: previous hospitalization at another health institution and/or intensive care center and/or previous use of antimicrobials at the hospital of origin and/or cutaneous injury or surgical wound containing purulent exudate. The second instrument served to collect microbiological data.

In 2008, the Hospital Infection Control Service (HICS) at the study hospital elaborated an admission protocol for patients previously hospitalized at other hospitals with a view to minimizing the dissemination 
of multi-resistant microorganisms. The protocol involves the establishment of contact precautions and nasal and anal swab collection for patients who attended to one of the above described clinical criteria. Nurses at the institution have been trained to apply the protocol and are responsible for assessing each patient, upon admission, for the indication of contact precautions and for swab collection.

The microbiology laboratory and the HICS defined the following resistant microorganisms: methicillin resistant Staphylococcus aureus, Extended-Spectrum Beta Lactamase (ESBCL) producing Escherichia coli and ESBL producing Klebsiella spp, Pseudomonas aeruginosa and Acinetobacter spp resistant or sensitive to meropenem or imipenem only, vancomycin resistant Enterococcus faecalis and Enterococcus faecium.

The primary researcher collected demographic and clinical data and microbiological results. The database was structured and analyzed through Statistical Package Social Science (SPSS), version 17.0 for Windows. To check the accuracy of isolation conducts upon admission, sensitivity and specificity ratios were calculated for the clinical criteria. Sensitivity refers to the test's ability to correctly identify individuals with a certain condition or illness and specificity to the test's ability to correctly identify individuals without a certain condition or illness.

\section{Results}

Table 1 shows the patients' distribution according to demographic and clinical variables. Out of 61 patients, $42(68.9 \%)$ were male. The mean age was 56.8 years ( $s d=15.1$ ), median 56 years, range from 18 to 86 years. Most patients (57.4\%) were hospitalized for clinical reasons, with a solid tumor (93.5\%) and, in some patients $(26.2 \%)$, invasive procedures were present upon admission.

Regarding the clinical criteria, 55.7\% had been hospitalized for seven days or more at common wards, $8.2 \%$ at intensive care units and $36.1 \%$ had been taking antibiotics therapy. It is highlighted that $49.2 \%$ of patients could not tell whether they had taken antibiotics or not and/or their health records showed no record of these.
Table 1 - Distribution of patients admitted to Hospital de Câncer de Barretos, coming from other hospitals ( $n=61)$, according to clinical and demographic characteristics and clinical criteria, Barretos, SP, Brazil, 2009

\begin{tabular}{|c|c|c|}
\hline Variables & $\mathbf{N}$ & $\%$ \\
\hline \multicolumn{3}{|l|}{ Gender } \\
\hline Female & 19 & 31.1 \\
\hline Male & 42 & 68.9 \\
\hline \multicolumn{3}{|l|}{ Age (years) } \\
\hline$\leq 20$ & 02 & 3.3 \\
\hline $21|-| 30$ & 02 & 3.3 \\
\hline $31|-| 40$ & 01 & 1.6 \\
\hline $41|-| 50$ & 11 & 18.0 \\
\hline $51 \mid-60$ & 25 & 41.0 \\
\hline$\geq 61$ & 20 & 32.8 \\
\hline \multicolumn{3}{|l|}{ Hospitalization type } \\
\hline Clinical & 35 & 57.4 \\
\hline Surgical & 21 & 34.4 \\
\hline Palliative & 05 & 8.2 \\
\hline \multicolumn{3}{|l|}{ Baseline illness } \\
\hline Solid tumor & 57 & 93.5 \\
\hline Leukemia & 03 & 4.9 \\
\hline Myeloma & 01 & 1.6 \\
\hline \multicolumn{3}{|c|}{ Presence of invasive procedures upon admission } \\
\hline Yes & 16 & 26.2 \\
\hline No & 45 & 73.8 \\
\hline \multicolumn{3}{|c|}{ Days hospitalized at the hospital or origin } \\
\hline$\leq \operatorname{Six}$ & 27 & 44.3 \\
\hline$\geq$ Seven & 34 & 55.7 \\
\hline \multicolumn{3}{|c|}{ Hospitalization at ICU of hospital of origin } \\
\hline Yes & 05 & 8.2 \\
\hline No & 56 & 91.8 \\
\hline \multicolumn{3}{|c|}{ Number of days hospitalized at ICU of hospital or origin } \\
\hline None & 56 & 91.8 \\
\hline Three & 02 & 3.3 \\
\hline Six & 02 & 3.3 \\
\hline Seven & 01 & 1.6 \\
\hline \multicolumn{3}{|l|}{ Antibiotics use at hospital of origin } \\
\hline Yes & 22 & 36.1 \\
\hline No & 09 & 14.7 \\
\hline Could not inform & 30 & 49.2 \\
\hline
\end{tabular}

As observed in Table 2, 13 patients did not comply with any criterion for the establishment of contact precautions upon admission, but 05 (16.7\%) showed positive cultures for multi-resistant microorganisms. Contact precaution measures were established later, after Hospital Infection Control Service professionals found out about the result. It is highlighted that $19.67 \%$ of patients complied with more than one clinical criterion. 
Table 2 - Distribution of patients admitted to Hospital de Câncer de Barretos, coming from other hospitals with a positive culture or not for multi-resistant microorganisms, according to clinical criteria for the establishment of contact precautions, Barretos, SP, Brazil, 2009

\begin{tabular}{|c|c|c|c|c|}
\hline \multirow{3}{*}{ Criteria } & \multicolumn{4}{|c|}{ Multi-resistant microorganisms } \\
\hline & \multicolumn{2}{|c|}{ No } & \multicolumn{2}{|c|}{ Yes } \\
\hline & $\mathbf{N}$ & $\%$ & $\mathbf{N}$ & $\%$ \\
\hline None & 08 & 25.8 & 05 & 16.7 \\
\hline Antibiotics use at the hospital of origin & 04 & 12.9 & 08 & 26.7 \\
\hline Days hospitalized at the hospital of origin $\geq$ seven days & 12 & 38.8 & 10 & 33.3 \\
\hline ICU hospitalization at hospital of origin & 01 & 3.2 & 0 & 0.0 \\
\hline Antibiotics use at hospital of origin and days hospitalized at hospital of origin $\geq$ seven days & 03 & 9.7 & 06 & 20.0 \\
\hline Antibiotics use at hospital of origin and ICU hospitalization at hospital of origin & 01 & 3.2 & 0 & 0.0 \\
\hline Days hospitalized at hospital of origin $\geq$ seven days and ICU hospitalization at hospital of origin & 02 & 6.5 & 01 & 3.3 \\
\hline Total & 31 & 100 & 30 & 100 \\
\hline
\end{tabular}

Table 3 shows data for nasal swab results when the patient was admitted to hospital. The most prevalent microorganism was Staphylococcus aureus, present in $19(31.1 \%)$ patients, only one $(1.6 \%)$ had been colonized with ESBL producing Klebsiella spp.

As for anal swab results, the most frequently identified microorganisms were Staphylococcus aureus in $20(32.8 \%)$ patients, followed by ESBL producing Escherichia coli in four (6.6\%), ESBL producing Klebsiella spp in three (4.9\%) and vancomycin resistant Enterococcus faecalis in one (1.6\%).

Table 3 - Distribution of patients admitted to Hospital de Câncer de Barretos, coming from other hospitals ( $n=61)$, according to presence of multi-resistant microorganism isolated from nasal and/or anal swab, Barretos, SP, Brazil, 2009

\begin{tabular}{lcccccc}
\hline \multirow{2}{*}{ Microorganism } & \multicolumn{2}{c}{ Nasal swab } & & \multicolumn{2}{c}{ Anal swab } \\
\cline { 2 - 3 } \cline { 6 - 7 } & N & $\%$ & & $\mathbf{N}$ & $\%$ \\
\hline $\begin{array}{l}\text { Methicillin resistant Staphylococcus } \\
\text { aureus }\end{array}$ & 19 & 31.1 & & 20 & 32.8 \\
$\begin{array}{l}\text { ESBL producing Klebsiella spp } \\
\text { ESBL producing Escherichia coli }\end{array}$ & 01 & 1.6 & & 03 & 4.9 \\
$\begin{array}{l}\text { Vancomycin/teicoplanin resistant } \\
\text { Enterococcus faecalis }\end{array}$ & 0 & 0.0 & & 04 & 6.6 \\
\hline
\end{tabular}

As observed in Table 4, the sensitivity and specificity of the clinical criteria adopted to establish contact precautions for patients coming from other health institutions who were admitted to Hospital de Câncer de Barretos corresponded to $90.0 \%$ and $6.5 \%$, respectively.

Regarding the five patients who did not attend to the criteria to establish contact precautions upon admission, three patients showed a positive swab for multi-resistant microorganisms, requiring the establishment of contact precautions.

Table 4 - Sensitivity and specificity of clinical criteria for the establishment of standard precautions for patients admitted to Hospital de Câncer de Barretos coming from other hospitals, Barretos, SP, Brazil, 2009

\begin{tabular}{|c|c|c|c|c|}
\hline \multirow{3}{*}{$\begin{array}{l}\text { Clinical criteria upon } \\
\text { admission }\end{array}$} & \multicolumn{4}{|c|}{ Multi-resistant microorganisms } \\
\hline & \multicolumn{2}{|c|}{ Yes $(n=30)$} & \multicolumn{2}{|c|}{ No $(n=31)$} \\
\hline & $\mathbf{N}$ & $\%$ & $\mathbf{N}$ & $\%$ \\
\hline No & 03 & 10.0 & 02 & 6.5 \\
\hline Yes & 27 & 90.0 & 29 & 93.5 \\
\hline
\end{tabular}

\section{Discussion}

The control of multi-resistant microorganisms is a current and pertinent theme, given the increasing evolution of microbial resistance, turning it into an increasing global problem, as the pharmaceutical industry does not manage to accompany the evolution in this resistance. The clinical criteria investigated in this study are appointed as risk factors for catching multiresistant microorganisms ${ }^{(11-12)}$.

The criterion previous use of antimicrobials is an important risk factor to catch multi-resistant microorganisms. The effect of this variable could not be assessed though, as 30 (49.2\%) patients could not inform whether they took antibiotics at the hospital or origin or this information had not been registered in the health file upon admission.

As for hospitalization time of seven days or more, out of 61 patients who came from other hospitals, 34 
(55.7\%) attended to this criterion. This data confirms that previous hospitalization is an important risk factor for colonization by multi-resistant microorganisms as, the longer the person stays in the hospital environment, the greater the possibility of catching and/or disseminating these microorganisms ${ }^{(13)}$.

A study ${ }^{(12)}$ that investigated risk factors for colonization by vancomycin resistant Enterococcus (VRE) identified that exposure to hospital environments, prolonged hospitalizations, ICU hospitalizations, presence of an onco-hematological disease, chemotherapy, kidney failure patients undergoing hemodialysis, transplanted, immune suppressed patients and patients using intravenous catheters were the most frequent factors.

It is highlighted that the risk factor hospitalization at an intensive care unit in the hospital of origin was identified in five ( $8.2 \%)$ patients, one of whom showed a positive culture for multi-resistant microorganisms.

Intensive care units concentrate the highest incidence rates of hospital infections and are considered epicenters for the emergence of microbial resistance due to the hospitalization of severe patients. In most cases, those patients take broad-spectrum antibiotics and are submitted to countless invasive procedures.

A study ${ }^{(14)}$ that investigated risk factors for hospital infection at an intensive care unit of a teaching hospital identified that patients previously hospitalized at ICU were at a 1.93 (CI: 1.48-2.49) higher risk of developing infections in comparison with patients coming from the community. Patients colonized by resistant microorganisms developed high infection rates (61.6\%) and a Relative Risk of 9.5 (CI: 7.7-11.7; $\mathrm{p}<0.05)$ in comparison with patients not colonized by resistant microorganisms. The most frequently isolated microorganisms were Acinetobacter baumanni (36.3\%), Pseudomonas aeruginosa (21.9\%), methicillin resistant Staphylococcus aureus (14.7\%), Klebsiella pneumonia (11\%) and Escherichia coli (7.8\%). Hence, patients from this unit continue as an important reservoir of multiresistant microorganisms and can disseminate them to other patients at the same unit, to other hospital sectors or, also, to other health institutions.

As for invasive procedures, 11 patients (18\%) were using a peripheral venous catheter and four $(6.6 \%)$ an indwelling urinary catheter upon admission. Although these were not part of clinical criteria for the establishment of contact precautions, intravenous catheter use was appointed as one of the most frequent risk factors for colonization by vancomycin resistant Enterococcus (VRE) ${ }^{(15)}$.
Regarding patients' nasal and anal swab results during hospitalization, it is highlighted that methicillin resistant Staphylococcus aureus (MRSA) was the most frequent in both nasal (31.1\%) and anal sways (32.8\%), followed by ESBL producing Klebsiella spp. (1.6\% in nasal and $4.9 \%$ in anal swabs), vancomycin/teicoplanin resistant Enterococcus faecalis (1.6\%) in anal swabs and E.coli in anal swabs (6.6\%)

In the last two decades, MRSA turned into the most prevalent and important resistant microorganism causing hospital infections. Besides the persistent trend, it also involves additional classes of antimicrobials, such as glycopeptides(16).

Patients colonized by MRSA are at greater risk of developing an infection by this microorganism at a later stage. A study(17) that investigated colonization upon admission and during hospitalization evidenced that $19 \%$ of patients colonized by MRSA upon admission and $25 \%$ of those colonized during hospitalization developed infection by this microorganism.

In this study, only one patient (1.6\%) tested positively for vancomycin/teicoplanin resistant Enterococcus faecalis (VRE). A study that investigated risk factors for rectal colonization by VRE showed that, although immune suppression, neutropenia and cancer as the baseline disease were more frequent in the colonized group, these variables showed no statistically significant relation with the colonization status. Previous use of antibiotics therapy, however, was associated with the acquisition of this microorganism, mainly the use of vancomycin and third-generation cephalosporins ${ }^{(12)}$.

Nevertheless, the prevalence of ESBL producing Klebsiella has been low, corresponding to $1.6 \%$ and $4.9 \%$ in nasal and anal swabs, respectively. A casecontrol study ${ }^{(18)}$ identified that $55.6 \%$ of isolated cultures of Klebsiella pneumoniae and $9.4 \%$ of isolated cases of E.coli were ESBL producing and that total mortality within 60 days was significantly higher among ESBL producing isolated cultures, evidencing the need for measures to prevent these micro-organisms.

The prevention and control of multi-resistant microorganisms represents one of the main challenges for Hospital Infection Control Services. Health institutions have used different control measures and some European countries have managed to maintain low MRSA prevalence rates through the adoption of active surveillance cultures and the establishment of contact precautions $^{(19)}$.

The sensitivity of contact precaution establishment criteria for patients coming from other hospitals was 
$90 \%$ and the specificity $6.5 \%$. It is highlighted that, out of eight patients who did not attend to isolation criteria upon admission, five (16.5\%) showed positive results for multi-resistant microorganisms. Thus, it can be inferred that, probably, these patients used antibiotics but could not inform this.

The introduction of a set of intervention, particularly active surveillance, the establishment of standard precautions and rapid testing to detect colonization reduced MRSA-caused bacteremia cases by $70 \%{ }^{(20)}$. The surveillance culture for MRSA was considered effective though, and its cost justified, when adopted at highrisk units, which contributes to decrease MRSA infection rates at the hospital(21). On the other hand, the use of clinical criteria to isolate patients colonized by MRSA and VRE showed to be effective and cheaper in comparison with the surveillance culture(8).

It is highlighted that the early identification of colonized patients enhances the adoption of preventive measures to avoid multi-resistant microorganism dissemination in hospitals. Contact precaution measures are very well-defined, but still have not been fully incorporated into different health institutions' practice $^{(22)}$.

Knowledge deficiencies on transmission mechanisms of multi-resistant microorganisms can contribute to low adherence to isolation measures ${ }^{(23)}$. A study(24) that investigated professionals' knowledge and behavior at an intensive care center regarding the adoption of contact precautions identified that nursing professionals presented approximately four times more chance $(O R=3.58$; CI 1.48-8.68) of adequate behaviors in comparison with other health professionals and that no statistically significant association existed between knowledge and behavior ( $p=0.196)$.

Not only the nursing team should adopt preventive measures for multi-resistant microorganisms, as other professional categories have actively participated in care delivery to hospitalized patients.

Despite limitations regarding the non-assessment of the antibiotic spectrum the patients used, previous hospitalization within six months before the current one, neutropenia intensity and duration, type of chemotherapy and presence of co-morbidities, the study permitted identifying that the sensitivity of the hospital's criteria for the establishment of contact precautions was $90 \%$, i.e. most patients with positive cultures for multi-resistant microorganisms were isolated upon admission.

\section{Conclusion}

This study reinforces the importance of adopting clinical criteria to admit patients from other hospital with a view to the prevention and control of multi-resistant microorganisms, as the sensitivity of the hospital's criteria for the establishment of contact precautions was $90 \%$. Also, further research is needed on other possible risk factors for this specific clientele's colonization.

\section{References}

1.Organização Mundial de Saúde (OMS). Vencendo a resistência microbiana. World health report on infections disease - 2000.[acesso 20 março 2010].Disponivel em:http://www.ccih.med.br/vencendoresistencia.html

2. Wernitz MH, Keck S, Swidsinski S, Veit SK. Cost analysis of a hospital-wide selective screening programme for methicillin-resistant Staphylococcus aureus (MRSA) carriers in the context of diagnosis related groups (DRG) payment. Clin Microbiol Infect. 2005;11(6):466-71.

3. Ministério da Saúde (BR). Portaria no 2.616 de 26 de maio de 1998 , que regulamenta as ações de controle de infecção hospitalar no país. Brasília(DF): Ministério da Saúde;1998.

4.Cavalcante NJF. Infecçãoem pacienteimunologicamente comprometido. In: Fernandes AT. Infecção hospitalar e suas interfaces na área da saúde. São Paulo (SP): Atheneu; 2000. p. 670-82.

5.Agência Nacional de Vigilância Sanitária (ANVISA) (BR). Investigação e controle de bactérias multirresistentes. Brasília (DF); 2007. 21 p.

6. Mendes AV, Sapolnik R, Mendonça N. New guidelines for the clinical management of febrile neutropenia and sepsis in pediatric oncology patients. J Pediatr.2007;63(2): 54-63.

7. Siegel JD, Rhinehart E, Jackson M, Chiarello L. Management of multidrug-resistant organisms in heslthcare settings. 2006. [acesso 6 jun 2009]. Disponível em: http://www.cdc.gov/ncidod/dhqp/pdf/ ar/mdroGuideline2006.pdff.

8. Morgan DJ, Day HR, Furuno JP, Young A, Johnson $\mathrm{JK}$, Bradham DD et al. Improving efficiency in active surveillance for methicillin-resistant Staphylococcus aureus or vancomycin-resistant Enterococcus at hospital admission. Infect Control Hosp Epidemiol. 2010;31(12):1230-5.

9. Lucet JC, Chevret S, Durand-Zaleski I, Chastang C; Regnier B. Prevalence and risk factors for carriage of methicillin-resistant Staphylococcus aureus at admission 
to the intensive care unit: results of a multicenter study. Arch Intern Med. 2003;163(2):181-8.

10. Furuno JP, McGregor JC, Harris AD, Johnson JA, Langenberg $P$, Venezia RA, et al. Identifying groups at high risk for carriage of antibiotic-resistant bacteria. Arch Intern Med. 2006;166(5):580-5.

11. Hidron AI, Kourbatova EV, Halvosa JS, Terrel B J, McDougal LK, Blumberg $\mathrm{HM}$ et al. Risk factors for colonization with methicillin-resistant Staphylococcus aureus (MRSA) in patients admitted to an urban hospital: emergence of community-associated MRSA nasal carriage. Clin Infect Dis. 2005;41(2):159-66.

12. Askarian M, Afkhamzadeh R, Monabbati A, Daxboeck $\mathrm{F}$, Assadian O. Risk factors for rectal colonization with vancomycin-resistant enterococci in Shiraz, Iran. Int J Infect Dis. 2008;12(2):171-5.

13. Ferrareze MVG, Leopoldo VC, Andrade D, Silva MFI, Haas VJ. Multi-resistant Pseudomonas aeruginosa among patients from an intensive care unit: persistent challenge? Acta Paul. Enferm.2006;20(1):7-11.

14. Oliveira AC, Kovner CT, Silva RS. Infecção hospitalar em unidade de tratamento intensivo de um hospital universitário brasileiro. Rev. Latino-Am. Enfermagem. 2010;18(2):233-9.

15. Centinkaya Y, Falk P, Mayhall G. Vancomycin-resistant enterococci. Clin Microbiol Rev. 2000;13(4):686-707.

16. Solberg CO. Spread of Staphylococcus aureus in hospitals: causes and prevention. Scand J Infect Dis. 2000;32(6): 587-95.

17. Davis KA, Moran KA, McAllister CK, Gray PJ. Multidrug-resistant Acinetobacter extremiliy infections in soldiers. Emerg Infect Dis.2005;1(8):1218-24.

18. Superti S V, Augusti G, Zavascki AP. Fatores de risco e mortalidade de infecções da corrente sanguínea por Klebsiella pneumoniae and Escherichia coli produtores de beta-lactamase de espectro estendido. Rev Inst Med Trop São Paulo. 2009;51(4):211-6.

19. Muto CA, Jernigan JA, Ostrowsky BE, Richet HM, Jarvis WR, Boyce JM, Farr BM. SHEA guideline for preventing nosocomial transmission of multidrug-resistant strains of Staphylococcus aureus and enterococcus. Infect Control Hosp Epidemiol. 2003; 24(5):362-86.

20. Chowers MY, Paitan Y, Gottesman BS, Gerber B, Ben-Nissan Y, Shirit P. Hospital-wide methicillin-resistant Staphylococcus aureus control program: a 5 year followup. Infect Control Hosp Epidemiol. 2009;30(8):778-81.

21. Clancy M, Graepler MT., Wilson M, Douglas I, Johnson J, Price CS. Active screening in high-risk unitis is an efecctive and cost-avoidant method to reduce the rate of methicillin-resistant Staphylococcus aureus infection in the hospital. Infect Control Hosp Epidemiol. 2006;2(10):1009-17.

22. Nichiata LYI, Gir E, Takahashi RF, Ciosak SI. Evolução dos isolamentos em doenças transmissíveis: os saberes na prática contemporânea. Rev Esc Enferm USP. 2004;38(1):61-70.

23. Moura JP, Gir E. Conhecimento dos profissionais de enfermagem referente à resistencia bacteriana a múltiplas drogas. Acta Paul Enferm. 2007;20(3):351-6. 24. Oliveira AC, Cardoso CS, Mascarenhas D. Conhecimento e comportamento dos profissionais de um centro de terapia intensiva em relação à adoção das precauções de contato. Rev. Latino-Am. Enfermagem. $2009 ; 17(5): 625-31$. 